http://jmscr.igmpublication.org/home/ ISSN (e)-2347-176x ISSN (p) 2455-0450

crossref DOI: https://dx.doi.org/10.18535/jmscr/v8i3.28

Journal Of Medical Science And Clinical Research

\title{
A Morphological study of variations in the shape of suprascapular notch in dry human scapula
}

\author{
Authors \\ Dr S.Revathi ${ }^{1}$, Dr Vino Victor Jesudas ${ }^{2}$ \\ ${ }^{1}$ III Year Post Graduate, MD Anatomy, Institute of Anatomy, Madurai Medical College, Madurai \\ ${ }^{2}$ Professor and Director, Institute of Anatomy, Madurai Medical College, Madurai
}

\begin{abstract}
Introduction: The suprascapular notch is a regular feature of the superior border of the scapula, medial to the root of the coracoid process. This suprascapular notch is converted into a foramen by the attachment of the superior transverse scapular ligament to its edges. The suprascapular nerve passes through this foramen while the suprascapular vessels pass above the ligament. The suprascapular nerve could be compressed due to variations in the shape of the suprascapular notch. The aim of this study is to evaluate the variations in the shape of the suprascapular notch and to compare it with the findings of the previous studies.

Materials and Methods: The present study was conducted on 180 dry human scapulae of unknown age \& sex obtained from the Institute of Anatomy, Madurai Medical College, Madurai. All the scapulae were examined macroscopically, first, for the presence or absence of the suprascapular notch and second, for the shape of the notch. The data were recorded and compared with the previous studies.

Observation: In this study we found that majority of the scapulae $94(52.22 \%)$ had U-shaped suprascapular notch followed by $42(23.33 \%)$ scapulae with J-shaped notch. V-shaped notch not found. In $16(8.88 \%)$ scapulae no notch was present. In 24 (13.33\%) scapulae, there was only a slight indentation at the site of the suprascapular notch. Complete ossification of the superior transverse scapular ligament was observed in $4(2.22 \%)$ scapulae.

Conclusion: The knowledge of variations in shape of the suprascapular notch will be helpful for orthopaedicians and neurologists in suspecting suprascapular nerve entrapment due to these anatomical variations.

Keywords: Suprascapular notch (SSN), Superior transverse scapular ligament (STSL), Suprascapular nerve entrapment syndrome.
\end{abstract}

\section{Introduction}

The scapula is a flat triangular piece of bone that lies on the poster lateral aspect of the thoracic cage and extend vertically from the second to the seventh rib. It has three borders (superior, medial, and lateral) and three angles (superior, inferior, and lateral). The superior border extends from the superior angle to the lateral angle. It is the thinnest and the shortest of the three borders. Near the root of the coracoid process, the superior border presents a notch called the suprascapular notch. This notch is converted into a foramen, called the suprascapular foramen, by the attachment of the superior transverse scapular ligament to its edges ${ }^{1}$. After arising from the upper trunk of the brachial plexus, the suprascapular nerve passes through 
this foramen and supplies the supraspinatus muscle and then descends lateral to the spine of the scapula along with the suprascapular vessels to supply the infraspinatus muscle. It also gives a twig to the shoulder joint ${ }^{2}$. According to Khan, ${ }^{3}$ the suprascapular notch is frequently bridged by bone. Overhead abduction of the shoulder joint exert traction on the suprascapular nerve present in the vicinity and leads to its compression. Studies revealed that the shape of the suprascapular notch is variable. It could be Ushaped or J-shaped or V-shaped or could be represented by a slight indentation only, or it could be absent, or it could be converted into a foramen by complete ossification of the superior transverse scapular ligament ${ }^{4-9}$. As the suprascapular nerve passes through the suprascapular foramen, it could be compressed due to variations in the shape of the suprascapular notch. The aim of this study is to evaluate the variations in the shape of the suprascapular notch and to compare it with the findings of the previous studies.

\section{Materials and Methods}

The present study was conducted on 180 dry human scapulae of unknown age \& sex obtained from the Institute of Anatomy, Madurai Medical College, Madurai. All the scapulae were examined macroscopically, first, for the presence or absence of the suprascapular notch and second, for the shape of the notch. The data were recorded and compared with the previous studies. Scapulae with damaged superior border were excluded from the study.

\section{Observation}

In this study we found that majority of the scapulae 94 (52.22\%) had U-shaped suprascapular notch followed by 42 (23.33\%) scapulae with Jshaped notch. V-shaped notch not found. In16 $(8.88 \%)$ scapulaeno notch was present. In 24 (13.33\%) scapulae, there was only a slight indentation at the site of the suprascapular notch. Complete ossification of the superior transverse scapular ligament was observed in $4(2.22 \%)$ scapulae.

The results of our study shown in Table 1

\begin{tabular}{|l|c|}
\hline \multicolumn{2}{|l|}{ Table 1: Showing the types of suprascapular notch } \\
\hline Shape of notch & Number of scapulae with percentage \\
\hline U-shaped & $94-52.22 \%$ \\
\hline V-shaped & 0 \\
\hline J-shaped & $42-23.33 \%$ \\
\hline Slight indentation & $24-13.33 \%$ \\
\hline Absent notch & $16-8.88 \%$ \\
\hline Complete ossification of suprascapular ligament & $4-2.22 \%$ \\
\hline
\end{tabular}

We compared our data with that of other authorsin Table 2

\begin{tabular}{|c|c|c|c|c|c|c|}
\hline \multirow[t]{2}{*}{ Author } & \multicolumn{6}{|c|}{ Shape of suprascapular notch (\%) } \\
\hline & $\mathrm{U}$ & V & $\mathrm{J}$ & $\begin{array}{c}\text { Slight } \\
\text { indentation }\end{array}$ & $\begin{array}{c}\text { Absent } \\
\text { notch }\end{array}$ & $\begin{array}{l}\text { Completely ossified superior } \\
\text { transverse ligament }\end{array}$ \\
\hline Iqbal et al. & 13.2 & 20 & 22 & 33.5 & 22.5 & - \\
\hline Nagaraj et al. & 26.92 & 1.92 & 43.26 & 2.88 & 23 & 2.88 \\
\hline Rubi et al & 40.31 & 7.75 & 21.31 & 26 & 17.44 & 3.1 \\
\hline Nandkishor et al. & 53.04 & 12.15 & 28.73 & 1.66 & 1.1 & 3.3 \\
\hline Vedha et al. & 53.2 & 5.6 & 5.2 & - & 21.2 & 9.6 \\
\hline Present study & 52.2 & - & 23.3 & 13.3 & 8.8 & 2.2 \\
\hline
\end{tabular}




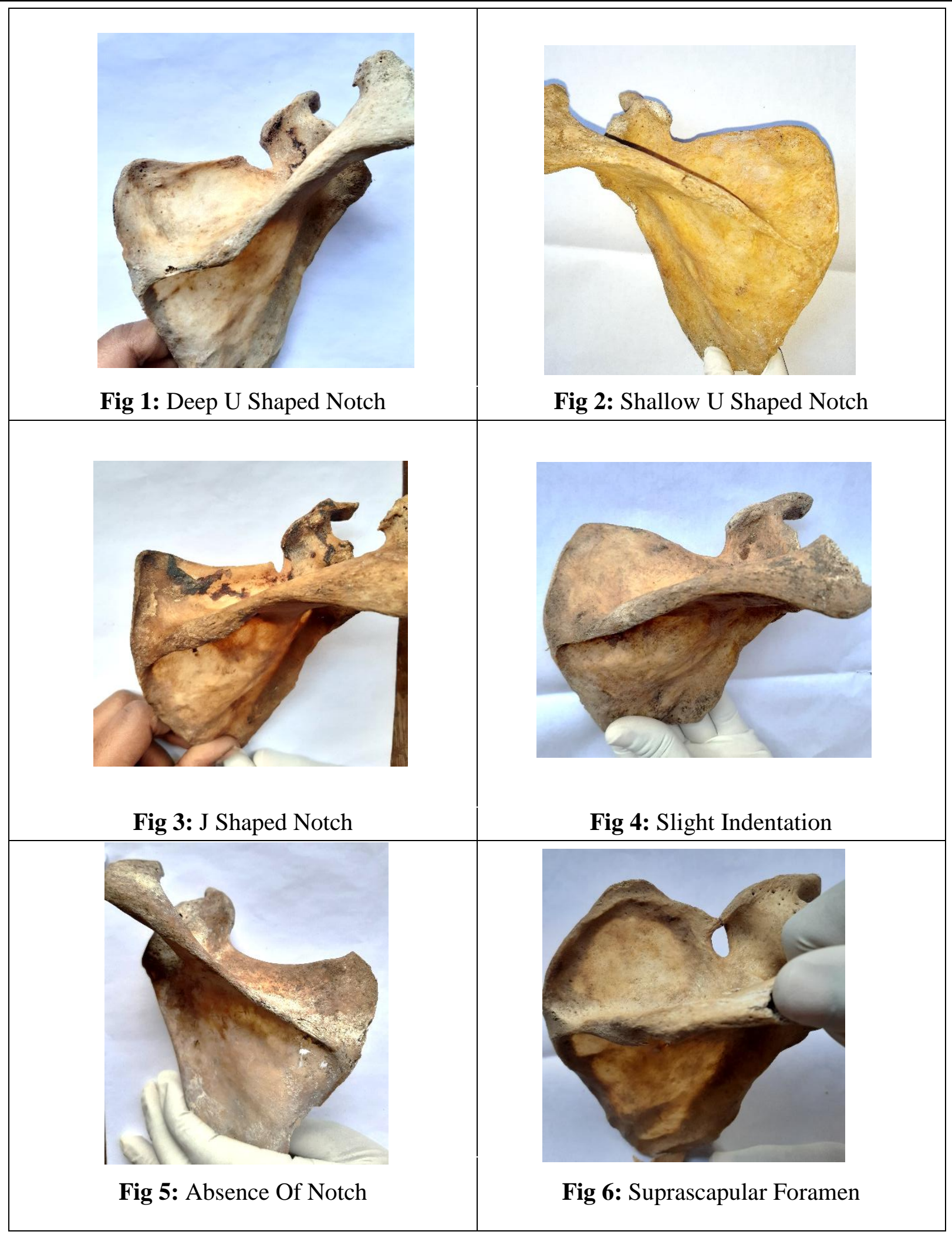

\section{Discussion}

The suprascapular notch classified into three distinct types ${ }^{5}$ :

1) U-shaped suprascapular notch, defined as having almost parallel sides with a round base.

2) J-shaped suprascapular notch defined as one limb is longer with curved base.
3) V-shaped suprascapular notch defined as having medial and lateral sides which converged towards a narrow base.

The suprascapular nerve entrapment is more common with a narrow V-shaped notch. A reduction in the height of the suprascapular foramen may predispose to entrapment of the 
suprascapular nerve and thus cause entrapment neuropathy.

$\mathrm{Soni}^{8}$ et al. have further included four more types in their classification. They are - indentation, absent notch, partial ossification of the suprascapular ligament, and complete ossification of the suprascapular ligament.

Rengachary ${ }^{9}$ et al. classified the suprascapular notch into six types based on inferior shape of the suprascapular notch as well as the degree of ossification of the superior transverse scapular ligament.

\section{Conclusion}

The knowledge of variations in shape of the suprascapular notch will be helpful for orthopaedicians and neurologists in suspecting suprascapular nerve entrapment due to these anatomical variations.

\section{References}

1. Standring S. Greys Anatomy. 40th ed. New York: Churchill Livingstone; 2008. p. 794-821.

2. McMinn RM. Last's Anatomy. 9th ed. UK: Churchill Livingstone; 2009. p. 68.

3. Khan MA. Complete ossification of the superior transversescapular ligament in an Indian male adult. Int $\mathbf{J}$ Morphol 2006;24:195-6.

4. Bayramoglu A, Demiryürek D, Tüccar E, Erbil M, Aldur MM, Tetik $\mathrm{O}$, et al. Variations in anatomy at the suprascapular notch possibly causing suprascapular nerve entrapment: An anatomical study. Knee Surg Sports Traumatol Arthrosc 2003;11: 393-8.

5. Natsis K, Totlis T, Tsikaras P, Appell HJ, Skandalakis P, Koebke J. Proposal for classification of the suprascapular notch: A study on 423 dried scapulas. Clin Anat 2007;20:135-9.
6. Iqbal K, Iqbal R, Khan SG. Anatomical variations in shape of suprascapular notch of scapula. J Morphol Sci 2010;27:1-2.

7. Nagaraj S, Krishnaiah MK, Kumar MP, Sherke AR. Study of morphological variations of suprascapularnotch. IOSR J Dent Med Sci2014;13:121-3.

8. Soni G, Malik VS, Shukla L, Chabbra S, Gaur N. Morphometric analysis of suprascapular notch. Internet $\mathrm{J}$ Biol Anthropol 2012;5. DOI: 10.5580/2b19.

9. Rengachary SS, Burr D, Lucas S, Hassanein KM, Mohn MP, Matzke H. Suprascapular entrapment neuropathy: A clinical, anatomical and comparative study. Part 2: Anatomical study. Neurosurgery 1979;5:447-51.

10. Saikia R, Baishya RJ, Deka B. Variations in the Shape of the Suprascapular Notch in Dry Human Scapula: An Anatomical Study. Int J Sci Stud 2017;5(1):187-190

11. Vedha et.al: A Morphological Study of Suprascapular Notch and Incidence of Ossification of Superior Transverse Scapular Ligament in South Indian Dry Scapulae, Int J Cur Res Rev 2017; 9(13); 45-49.

12. Dr. Nand Kishor et al; Morphological variations in shape of suprascapular notch in dry human scapula; International Journal of Medical and Health Research 2017; 3(11);94-96. 